Send your letters to the Editor,

British Dental Journal,

64 Wimpole Street

London

W1G 8YS

Email bdj@bda.org

Priority will be given to letters less than 500 words long.

Authors must sign the letter, which

may be edited for reasons of space.

\section{PROTON PUMP INHIBITORS}

Sir, the burning mouth syndrome (BMS) is well recognised as having a range of possible aetiological factors though the cause often remains unidentified. ${ }^{1,2}$ Amongst factors associated with BMS are various drugs, notably antiretrovirals, anticonvulsants, hormones and particularly antihypertensives that act upon the angiotensin-renin system ${ }^{3}$ such as captopril.

A 52-year-old female patient presented with BMS-like symptoms affecting all her oral mucosae (whereas BMS more usually affects the tongue, and sometimes the lips and palate) but no xerostomia, and was adamant that the problem was related to her use for acid reflux of omeprazole, a proton pump inhibitor commonly used to manage peptic ulceration or gastro-oesophageal reflux. Unfortunately, change to a different agent of the same class (lansoprazole) though resulting in resolution of the burning mouth sensation, caused her to develop a rash.

Omeprazole is essentially a prescription-only medicine in the UK but a pack of 28 tablets can be purchased OTC. It is recognised to sometimes cause dry mouth ${ }^{4}$ - and dryness can sometimes underlie BMS - and the British National Formulary also includes as possible adverse oral effects, taste changes and 'stomatitis'. Whether the latter term could cover symptoms such as noted by the present patient is unclear but internet sites also mention burning mouth as a possible reaction to omeprazole.

It would be interesting to learn of any other possible cases that might support or refute the strength of this association but, in any event, it highlights the need to consider the full drug history in relation to oral health issues.

\section{Scully CBE \\ By email}

1. Van der Waal I. The burning mouth syndrome. Mosby, 1990

2. Scala A, Checchi L, Montevecchi M, Marini I, Giamberardino M A. Update on burning mouth syndrome: overview and patient management. Crit Rev Oral Biol Med 2003; 14: 275-291.

3. Salort-Llorca C, Minguez-Serra M P, Silvestre FJ. Drug-induced burning mouth syndrome: a new etiological diagnosis. Med Oral Patol Oral Cir Bucal 2008; 13: E167-E170.

4. Teare J P, Spedding C, Whitehead M W, Greenfield S M et al. Omeprazole and dry mouth. Scand J Gastroenterol 1995; 30: 216-218.

DOI: 10.1038/sj.bdj.2010.162

\section{BLIND EYE}

Sir, the letter Back door dentistry from S. C. Bazlinton in Essex (BDJ 2009; 207: 567 ) is interesting as was the usual reply from the GDC who of course have the profession's interest at heart.

For some years now I have retired from working as a dental surgeon. Now if in future I decided to set up as an unregistered back door dentist intending only to make dentures to the public would the GDC turn a blind eye to my activities?

E. Hing

Chigwell

DOI: 10.1038/sj.bdj.2010.163

\section{NO GOOD REASON}

Sir, I would be interested to know why the Journal saw fit to publish another article by Dr Lewis (BDJ 2009; 207: 525526) when it adds little to his previous papers of 1981 and 1998. Equally, I'm not sure why Dr Lewis saw fit to seek publication in this country where his battle seems to be already won. He quotes the continued use of formocresol by dentists in the United States but in Europe the use of formocresol has never been high and has now virtually ceased since the guidelines from the British Society of Paediatric Dentistry were published in $2006{ }^{1}$

Dr Lewis dismisses the recent review by Milnes ${ }^{2}$ in one sentence but anyone who has read this review would be much less convinced of the problem of formocresol than Dr Lewis appears to be.

As noted in the IARC Monograph on Carcinogenic Risk quoted by Dr Lewis, formaldehyde is an essential metabolic intermediate in all cells. Exogenous formaldehyde reacts rapidly at the site of contact and is swiftly metabolised by human erythrocytes which contain formaldehyde dehydrogenase. ${ }^{3}$

Thus it is not surprising that a recent well conducted study in Colorado has found that in 30 children undergoing formocresol pulpotomies formaldehyde was undetectable in the circulation above baseline plasma concentration and that cresol was undetectable.

The IARC Monograph found that there was evidence for the carcinogenicity of formaldehyde in persons chronically exposed in such industries as bakelite manufacture. The cancers were in areas directly exposed to the formaldehyde such as the nasopharynx and the lungs where chronic damage over a number of years took place. The evidence for cancers at distal sites was much less convincing which is not surprising in view of the rapid metabolism of formaldehyde as noted above. Although some workers have proposed an increased risk of leukaemia the evidence is not at all convincing and exposure to formaldehyde has not been shown to damage bone marrow presumably because it is metabolised before reaching it. 
As pointed out by Milnes ${ }^{2}$ 'There can be no doubt that a reparative, biologic approach to pediatric pulp therapy is preferable to the absolutist, devitalization approach of formocresol pulpotomy' but although other protocols for managing deep caries in primary teeth are now in common use, Patchett et al. ${ }^{5}$ noted that 'Presently, in Newcastle, the treatment of choice for nonvital primary molars is extraction since there is little evidence of an alternative medicament which is as effective as formocresol and which exhibits minimal technique sensitivity'.

Should we not balance the damage done from removing so many teeth from young children against the unproven damage done by formocresol pulpotomies?

Perhaps we should ask if we have thrown the baby out with the bathwater for no good reason?

J. Page

Portsmouth

1. Rodd H D, Waterhouse P J, Fuks S A, Fayle SA, Moffat M A. UK National Clinical Guidelines in Paediatric Dentistry Int J Paediatr Dent 2006 16(Suppl 1): 15-23.

2. Miles A R. Is formocresol obsolete? A fresh look at the evidence concerning safety issues. $J$ Endod 2008; 34 Suppl: 540-546 and Pediatr Dent 2008: 30: $237-246$

3. Formaldehyde, 2-Butoxyethanol and i-tert-Butoxypropan-2-ol IARC Monograph on the Evaluation of Carcinogenic Risks to Humans (1006) Vol 88 Lyon, France.

4. Kahl J, Easton J, Zuk J, Wilson S, Galinkin J. Formocresol blood levels in children receiving treatment under general anesthesia. Pediatr Dent 2008: 30: 393-399.

5. Patchett $C L$, Srinivasan V, Waterhouse P J. Is there life after Buckley's formocresol? Part II - Development of a protocol for the management of extensive caries in the primary molar. Int J Paediatr Dent 2006; 16: 199-206.

DOI: 10.1038/sj.bdj.2010.164

\section{TOOTH RELICS}

Sir, I was most interested in the paper on St Apollonia's tooth by Skrobonja et al. (BDJ 2009; 207: 499-502) in which a tooth relic in the cathedral treasury in Rab (Croatia) is described. Whilst it is possible that this tooth really is a relic of St Apollonia it must be recognised that, as the authors state, there are very many instances of fraud which occurred in mediaeval times when false claims were made about so called relics. There is no evidence that the autentica provides a guarantee that the relic is authentic, as claimed by the authors, since these seals were not recognised until 1543, some 1,300 years after St Apollonia's martyrdom.

The authors cite the ten churches listed by Walsh as having relics of St Apollonia. There are, however, numerous other relics purported to be those of the saint. She must have been a remarkable person if even a small fraction of these are correct. It is said that Philip II of Spain, an avid collector of relics, managed 'to amass all 290 holy teeth from the mouth of Saint Apollonia'.

I am aware of two existing relics in England attributed to St Apollonia, one in the Victoria and Albert Museum and the other at the Anglican Shrine at Walsingham. In both cases, unlike the Croatian one, the relic is a small fragment of tooth or bone. There was also a relic in the chapel at St Michael's Mount, Cornwall said to be from St Apollonia. That relic is no longer there.

The authors make much of the fact that it could be St Apollonia's tooth as it comes from a young person. However, there is considerable doubt as to the age of the saint when she was martyred. Although she is generally depicted as a young woman many versions of her history describe her as an aged virgin.

There are some 56 representations of St Apollonia in British churches, mainly in stained glass or painted on rood screens. All but one of these is described by Beal ${ }^{2}$ but there is another one on a rood screen at Hennock, Devon which I found subsequent to preparing that list.

\section{J. F. Beal MBE}

Leeds

1. Fuentes $C$ The buried mirror: reflections on Spain and the New World. p 164. London: Andre Deutsch, 1992

2. Beal J F. Representations of St Apollonia in British churches. Dental Hist 1996; 30: 3-19.

DOI: $10.1038 /$ sj.bdj.2010.165

\section{MAGNIFIED JOY}

Sir, I can only be fully supportive of any recent discussion ${ }^{1}$ and research $^{2}$ involving photography and dentistry but I would just like to add to the discussion and draw attention to the benefits of providing this through the use of an operating microscope.

Although microscopes were introduced not too long ago for use in endodontic treatment, the joy of using magnification and illumination in this way extends to many aspects of dentistry. With experience and practice an operating microscope can be used routinely for much of the time in assessment, treatment and communication in general practice. Once a camera is set up to look through the microscope the image of what is seen through the microscope can be recorded consistently and hygienically at any stage of diagnosis, treatment and advice.

I use a miniDV camcorder that also takes excellent single 'photoshots'. My nurse uses a 'bagged' remote control to operate the camera. It is minimal interruption to our work pattern. Screens run from the same camera display 'real time' presentations of procedures for the benefit of support staff, colleagues and not least the patient if they would also like to watch. We can also video record at the same time.

Microscope dentistry takes commitment but it is achievable. Successful, ergonomic and routine application is very dependent on good nursing support, training and the selection of appropriate equipment and instrumentation. The logic of working this way, as in all surgical disciplines that have adopted magnification and illumination, is unbeatable. If you can see or see better you can do better. With the added benefit of applying photography and video 'on tap' it is a truly complete and satisfying way to work.

\section{English} Norwich

1. Naqvi A. Compact cameras. Br Dent J 2010; 208: 3 .

2. Morse G A, Haque M S, Sharland M R, Burke F J T. The use of clinical photography by UK general dental practitioners. Br Dent J 2010; 208: E1.

DOI: 10.1038/sj.bdj.2010.166 